\title{
Seasonal changes in the abundance and composition of picophytoplankton in relation to the occurrence of 'Kyucho' and bottom intrusion in Uchiumi Bay, Japan
}

\author{
Toshiya Katano ${ }^{1,3, *}$, Atsushi Kaneda ${ }^{1}$, Hidetaka Takeoka ${ }^{1}$, Shin-ichi Nakano ${ }^{1,2}$ \\ ${ }^{1}$ Center for Marine Environmental Studies, Ehime University, Bunkyo-cho 3, Matsuyama, Ehime, 790-8577, Japan \\ ${ }^{2}$ Faculty of Agriculture, Ehime University, Tarumi 3-5-7, Matsuyama, Ehime, 790-8566, Japan \\ ${ }^{3}$ Present address: Department of Life Science/Environmental Science, Hanyang University, Seoul, 133-791, Korea
}

\begin{abstract}
Uchiumi Bay experiences intermittent physical events of 'Kyucho' and bottom intrusion. A Kyucho is an intrusion of warm surface water from the Kuroshio in the Pacific Ocean. Bottom intrusion, which contains a large amount of nitrates, phosphates, and silicates, slips through just above the continental shelf. We investigated seasonal changes in the abundance of Prochlorococcus, Synechococcus, and eukaryotic picophytoplankton while monitoring Kyucho and bottom intrusion from March to October 2002. Kyucho and bottom intrusion frequently occurred from June to September. Relatively high concentrations of nitrate + nitrite $\left(>0.8 \mu \mathrm{mol} \mathrm{N}^{-1}\right)$ and phosphate $\left(>0.1 \mu \mathrm{mol} \mathrm{P} \mathrm{^{-1 }}\right)$ were found when bottom intrusion occurred. The cell densities of Prochlorococcus were relatively high $\left(>1 \times 10^{4}\right.$ cells ml $\left.^{-1}\right)$ when Kyucho occurred. Those of Synechococcus were high $\left(2\right.$ to $30 \times 10^{4}$ cells $\mathrm{ml}^{-1}$ ) during the period of thermal stratification except in July, when bottom intrusion occurred. The cell densities of eukaryotic picophytoplankton were high $\left(2\right.$ to $\left.8 \times 10^{4} \mathrm{cells} \mathrm{ml}^{-1}\right)$ in May and July. To examine the effects on picophytoplankton growth of the nutrients supplied by bottom intrusion, we conducted nutrient-enrichment experiments. The growth rates of Prochlorococcus and Synechococcus were not stimulated by the addition of any kinds of nutrients. The growth rates of Prochlorococcus were negative in most cases. In July, the growth rate of eukaryotic picophytoplankton was stimulated by nitrate and phosphate additions. Thus, Prochlorococcus detected in Uchiumi Bay might have been transported by Kyucho from the Pacific Ocean and could therefore not grow vigorously. Synechococcus may have been flushed out by bottom intrusion, and its growth was not limited by the nutrient concentrations. Eukaryotic picophytoplankton was abundant in spring, and its growth might have been limited by the nutrient concentrations in some cases. These results suggest that Kyucho and bottom intrusion have different effects on the abundance and growth rate of the 3 picophytoplankton groups.
\end{abstract}

KEY WORDS: Bottom intrusion $\cdot$ Kyucho $\cdot$ Prochlorococcus $\cdot$ Synechococcus · Eukaryotic picophytoplankton $\cdot$ Growth response $\cdot$ Nutrient supply

Resale or republication not permitted without written consent of the publisher

\section{INTRODUCTION}

Picophytoplankton is an important component of primary producers, especially in oligotrophic marine environments (Stockner \& Antia 1986, Weisse 1993). The major components of picophytoplankton are Prochlorococcus, Synechococcus, and eukaryotic picophytoplankton. The abundance of these picophytoplankton groups is strongly affected by nitrogen and phosphorus supplies (Glover et al. 1988, Del Amo et al.
1997, Agawin et al. 2000, Duarte et al. 2000). For example, Glover et al. (1988) reported a Synechococcus bloom after a nanomolar increase of nitrate in the Sargasso Sea. In contrast, Moutin et al. (2002) suggested that Synechococcus might grow rapidly after an episodic phosphate increase in phosphate-depleted environments, such as the Mediterranean Sea (Vaulot et al. 1996). In different marine systems, the nutrient supply has a different effect on the abundance of picophytoplankton. 
Recently, a difference in the nitrogen utilization between Synechococcus and Prochlorococcus was clarified. Synechococcus utilizes various forms of nitrogen, such as nitrate, nitrite, ammonium, and urea (Waterbury et al. 1986, Lindell et al. 1998, Moore et al. 2002), but some Synechococcus strains do not utilize urea for growth (Waterbury et al. 1986, Collier et al. 1999). Prochlorococcus utilize urea and nitrite but not nitrate (Moore et al. 2002). An analysis of the complete genome sequence showed that Prochlorococcus does not use nitrate because of a lack of nitrate permease and nitrate reductase genes (Moore et al. 2002). Thus, in addition to dissolved nitrogen concentrations, the available forms of nitrogen may affect the composition of picophytoplankton in marine environments, though the nitrogen utilization of eukaryotic picophytoplankton is currently unknown.

In contrast, few studies have researched the effects of the phosphorus supply on the abundance of picophytoplankton in marine environments, though picophytoplankton is phosphate-limited in some cases (Vaulot et al. 1996, Thingstad et al. 1998). Moutin et al. (2002) reported that Synechococcus might be well adapted to exploit the episodic phosphorus supply resulting from physical events such as wind-induced turbulence and upwelling. The effect of the phosphorus supply on the abundance of picophytoplankton and its growth should be further studied.

In Uchiumi Bay, located in the southern part of the Uwa Sea, Japan, there are intermittent physical events of 'Kyucho' and bottom intrusion. A Kyucho is an intrusion of warm surface water from the Kuroshio in the Pacific Ocean (Akiyama \& Saitoh 1993, Takeoka et al. 2000). Thus, a Kyucho contains scarce amounts of nutrients. Bottom intrusion is deep, cold water that slips through just above the continental shelf (Kaneda et al. 2002a,b); this cold water contains a large amount of nitrates, phosphates, and silicates (Koizumi 1991, Koizumi \& Kohno 1994, Koizumi et al. 1997, Takeoka et al. 2000, Kaneda et al. 2002a,b). Koizumi et al. (1997) noted that, after an occurrence of bottom intrusion, the cell density of diatoms in Shitaba Bay of the Uwa Sea increased with the use of the supplied nutrients. Thus, bottom intrusion is an important supply of nutrients for phytoplankton in the Uwa Sea.

The trophic state of the water in Uchiumi Bay is oligo- to mesotrophic based on its chlorophyll level (Tomaru et al. 2002). The concentration of chlorophyll $a$ in the $<2 \mu \mathrm{m}$ fraction compared to the total fraction ranged between 5 and $60 \%$ (Hirose et al. unpubl. data). Thus, picophytoplankton might be an important primary producer in the bay. Prochlorococcus, Synechococcus, and eukaryotic picophytoplankton have been detected using flow cytometric analysis (T. Hirose et al. unpubl.). As described above, nutrients supplied by bottom intrusion strongly affect the cell densities of diatoms in the Uwa Sea (Koizumi \& Kohno 1994). However, the effects of the nutrient supply on the abundance and composition of picophytoplankton have not yet been evaluated. The differences in the growth rate responses of the 3 picophytoplankton groups to the supply of nitrate and phosphate might cause changes in the picophytoplankton composition.

The objective of the present study was to clarify the seasonal changes in the abundance and composition of picophytoplankton in relation to the occurrence of Kyucho and bottom intrusion. In addition to the investigation of seasonal changes in picophytoplankton, we conducted monthly in situ incubation experiments to evaluate the effects of nutrient addition on the growth rate of the 3 picophytoplankton groups.

\section{MATERIALS AND METHODS}

Water temperature monitoring and sampling. To monitor the occurrence of Kyucho and bottom intrusion, the water temperature was measured every 30 min with a thermistor chain at 2, 10, 20, 30, 40, 50, and $60 \mathrm{~m}$ depths at Stn Ut (Fig. 1). Field monitoring and in situ incubation experiments were conducted once a month from March to October 2002 at Stn Ub in Uchiumi Bay (Fig. 1). Water samples were collected from depths of $0,2,5,10,15,20,30,40$, and 50 m using a 61 Van-Dorn water sampler. The water temperature was measured vertically with a CTD profiler (Arec Electronics, Japan). The samples were stored in a 101 polyethylene tank and brought to the laboratory.

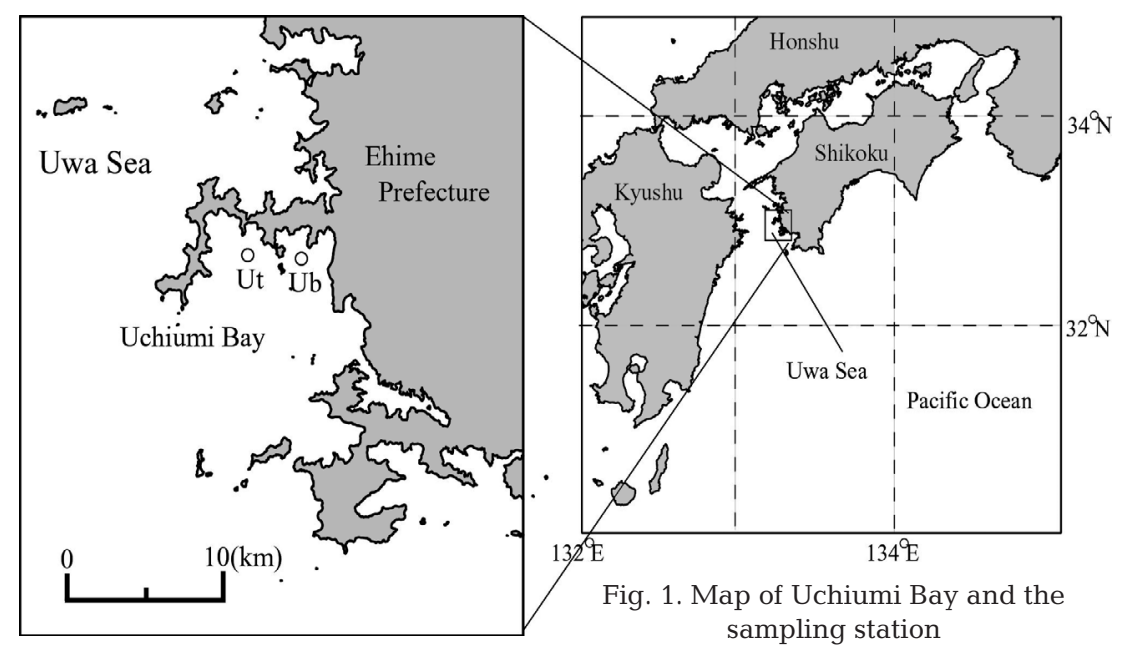


The water samples were filtered through 0.2 or $2.0 \mu \mathrm{m}$ Nuclepore filters (Whatman). The filtrate of the former was used for the determination of nutrient concentrations, and that of the latter was used for the enumeration of the cell density of picophytoplankton. Nitrate + nitrite, ammonium, and phosphate concentrations were determined with an autoanalyzer (TRAACS 800, BRAN+LUEBEE).

Flow cytometric counts. The cell density of picophytoplankton was determined with a flow cytometer (FACSvantage SE, Becton Dickinson) equipped with a water-cooled Argon laser (488 nm, 1 W, Coherent). The forward scatter detector of the flow cytometer was changed from a photodiode to a photomultiplier tube to increase the sensitivity. Thus, our flow cytometer, in conjunction with the high-power water-cooled Argon laser, had enough sensitivity to detect small phytoplankton, such as Prochlorococcus (Fig. 2).

Flow cytometry sheath fluid was made by filtering seawater through a $0.1 \mu \mathrm{m}$ pore-size membrane filter (Millipore). The forward scatter, side scatter, and 3 flu-
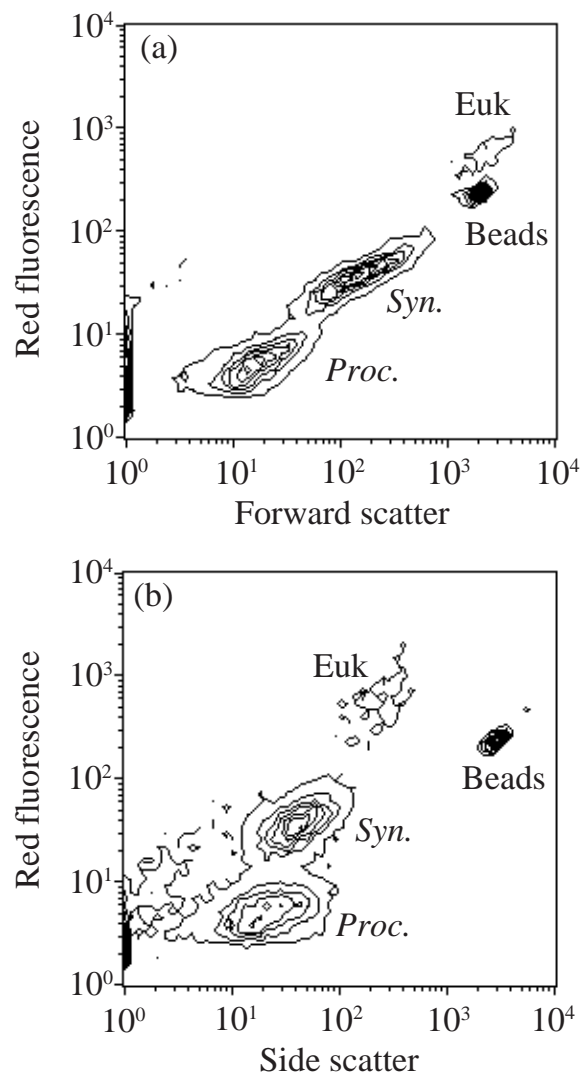

Fig. 2. Contoured plots of flow cytometric analysis for Prochlorococcus (Proc.), Synechococcus (Syn.), and eukaryotic picophytoplankton (Euk); (a) forward scatter vs. red fluorescence, and (b) side scatter vs. red fluorescence. The lines in the panels show a linear density scale. The noise on the forward scatter is visible at $<2$, and hence, is well below the signal of Prochlorococcus orescence intensities (red, 675 to $715 \mathrm{~nm}$; orange, 564 to $586 \mathrm{~nm}$; and green, 515 to $545 \mathrm{~nm}$ ) were recorded on each picophytoplankton cell. The instrument threshold was set to red fluorescence in order to not detect heterotrophic organisms. All parameters were normalized with $2 \mu \mathrm{m}$ fluorescent beads (Polyscience). The beads were also used as the internal standard for the enumeration of Prochlorococcus, Synechococcus, and eukaryotic picophytoplankton cells (Olson et al. 1993).

Ocean Data View software was used to make contoured plots for water temperature, salinity, nutrient concentrations, and picophytoplankton cell densities (Schlitzer, http://www.awi-bremerhaven.de/GEO/ODV/).

In situ incubation experiments. Samples collected from a depth of $10 \mathrm{~m}$ were filtered through a $0.2 \mu \mathrm{m}$ Gelman culture capsule filter and a $2.0 \mu \mathrm{m}$ Nuclepore filter. In the $<2.0 \mu \mathrm{m}$ filtrate, most of picophytoplankton grazers were probably removed. The filtrates $(2.0 \mu \mathrm{m}: 0.2 \mu \mathrm{m})$ were mixed with ratios of 3:7 in March and April and 1:9 in May to October; they were then poured into $300 \mathrm{ml}$ polycarbonate bottles. Thus, in our experiments, the removal of grazers and the dilution of the sample resulted in a reduction in the amount of grazing on the phytoplankton (Fahnenstiel et al. 1991), though grazing still occurred at a negligible level. Hence, we estimated gross growth rates rather than net growth rates. $\mathrm{KNO}_{3}, \mathrm{NH}_{4} \mathrm{Cl}$, urea, and/or $\mathrm{NaH}_{2} \mathrm{PO}_{4}$ were added to each bottle at a final concentration of $15 \mu \mathrm{mol} \mathrm{N}{ }^{-1}$ and $1 \mu \mathrm{mol} \mathrm{Pl} \mathrm{l}^{-1}$. Eight nutrient-enrichment treatments were prepared in triplicate: control (no addition), +nitrate, +ammonium, +urea, +phosphate, +nitrate \& phosphate, +ammonium \& phosphate, and +urea \& phosphate. The bottles thus prepared were incubated near the sampling station at a $10 \mathrm{~m}$ depth for $1 \mathrm{~d}$. At time zero and at the end of the incubation, subsamples for the enumeration of picophytoplankton were taken and fixed with glutaraldehyde at a final concentration of $1 \%$ and stored in liquid nitrogen. The growth rate, $\mu$, was calculated from the equation $\mu=\ln (N f / N 0) / t$, where $N 0$ and $N f$ are the cell densities at time zero and after $1 \mathrm{~d}$ of incubation, respectively, and $t$ is the incubation period. One-way ANOVAs were carried out using Kaleida Graph v. 3.5 (Synergy Software) to test for differences among treatments and between treatments; subsequently, multiple comparisons were carried out using Tukey's test with a discrimination level of $\mathrm{p}<0.05$.

\section{RESULTS}

\section{Seasonal changes in water temperature and nutrient concentrations}

The surface water temperature at Stn Ut gradually increased to $20^{\circ} \mathrm{C}$ at the end of May. From June to September, the surface water temperature was highly 
variable, ranging between 20 and $28^{\circ} \mathrm{C}$ at a $2 \mathrm{~m}$ depth and between 18 and $27^{\circ} \mathrm{C}$ at a $60 \mathrm{~m}$ depth. These large fluctuations were due to the occurrence of Kyucho and bottom intrusion (Fig. 3). We found 9 occurrences of Kyucho ( $K 1$ to $K 9$ ) and 8 occurrences of bottom intrusion (B1 to B8). $K 2, K 6$, and $K 9$ corresponded to our sampling dates on 12 June, 2 August, and 11 September, respectively, and B4 corresponded to that on 12 July (Fig. 3a).

Changes in the water temperature at Stn Ub (Fig. 3) were similar to those at Stn Ut (Fig. 4a). The water temperature in the whole water column decreased in July because of the occurrence of bottom intrusion and increased again in August. In October, the surface water temperature decreased to $23^{\circ} \mathrm{C}$, and the water column became almost isothermal.

Salinity gradually decreased from May (>34.6 PSU) to September (34.0 PSU) and increased from September to October (34.4 PSU, Fig. 4b), indicating that there was an exchange of seawater in Uchiumi Bay attrib-
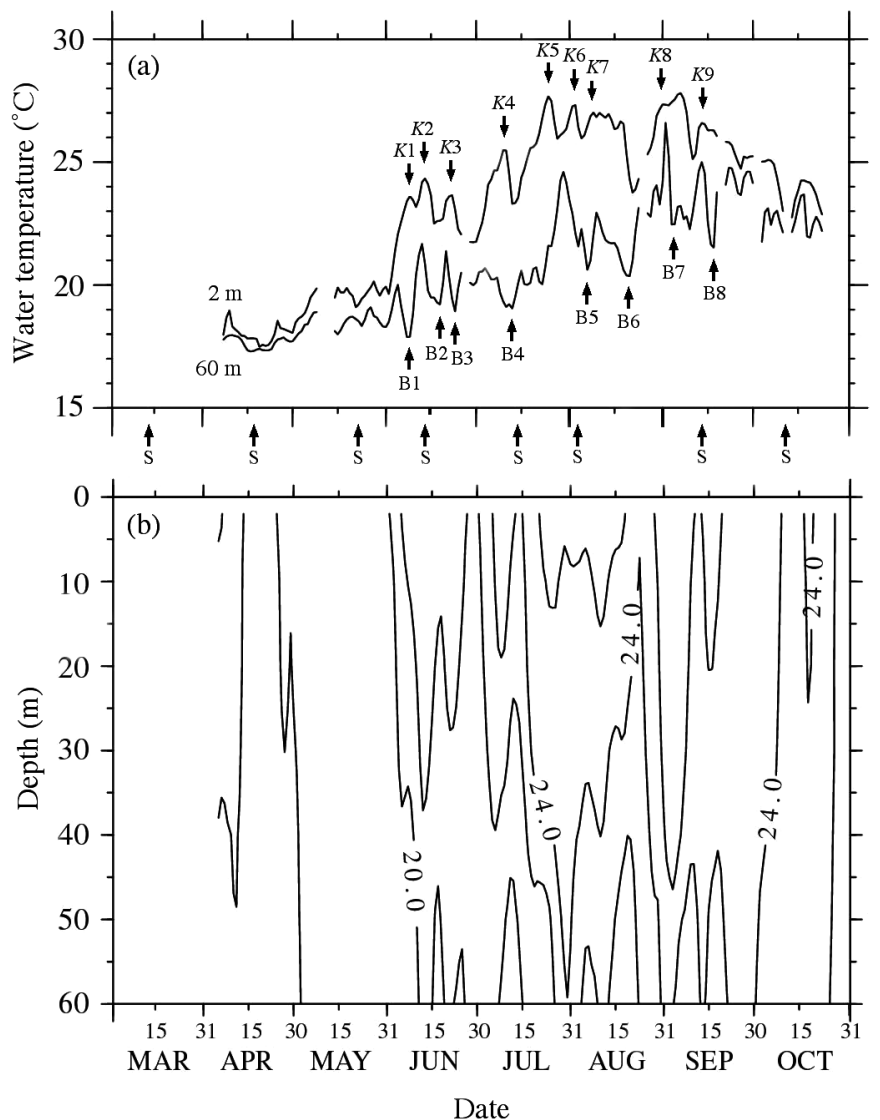

Fig. 3. Seasonal changes in (a) water temperature at depths of 2 and $60 \mathrm{~m}$ at Stn Ut, and in (b) vertical distributions of water temperature. The occurrences of Kyucho $(K)$ and bottom intrusion (B) are shown with arrows. The numbers after $K$ and B indicate the times of the occurrences after March 2002. Sampling dates (S) are indicated with arrows at the bottom of (a) uted to the occurrence of both Kyucho and bottom intrusion.

Nitrate + nitrite and ammonium concentrations varied from below the detection limit to $3.74 \mu \mathrm{mol} \mathrm{N}{ }^{-1}$

(a) Temperature $\left({ }^{\circ} \mathrm{C}\right)$

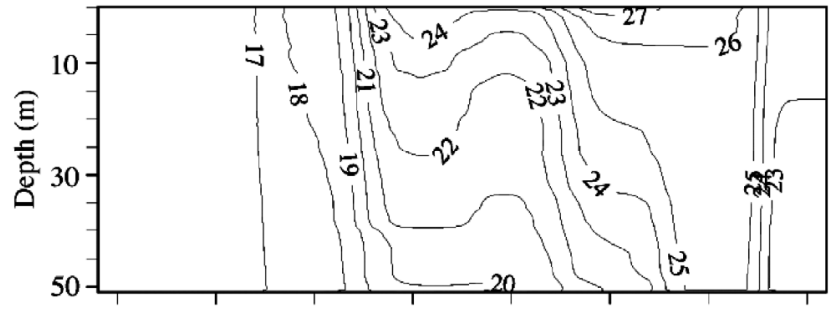

(b) Salinity (PSU)

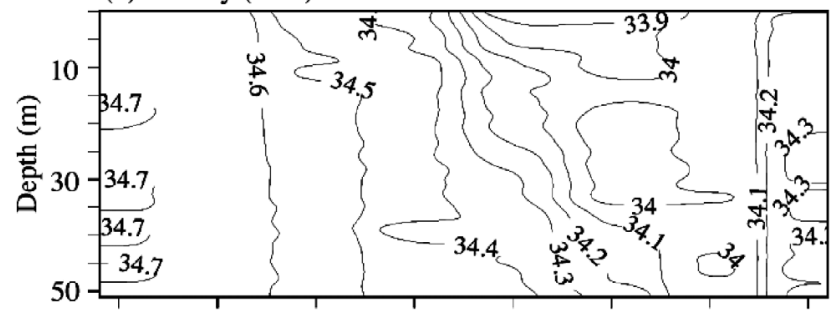

(c) Nitrate + nitrite $\left(\mu \mathrm{mol} \mathrm{N} \mathrm{l}^{-1}\right)$

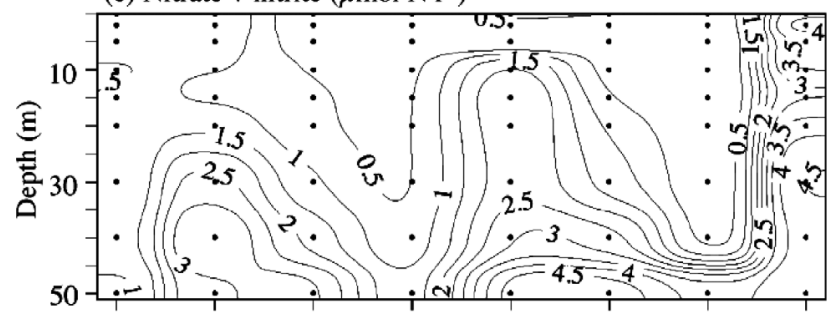

(d) Ammonium ( $\mu \mathrm{mol} \mathrm{N} \mathrm{I}^{-1}$ )

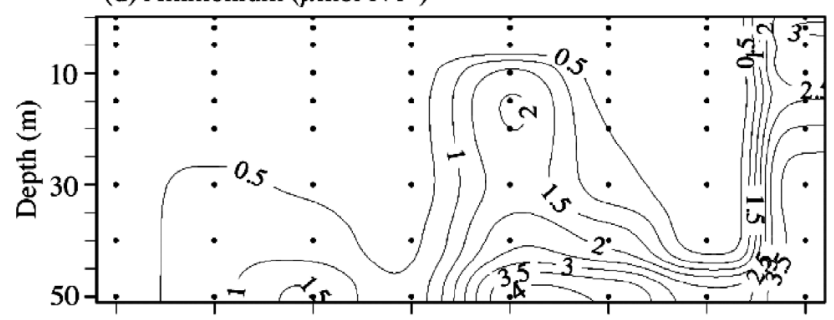

(e) Phosphate $\left(\mu \mathrm{mol} \mathrm{P} \mathrm{I}^{-1}\right)$

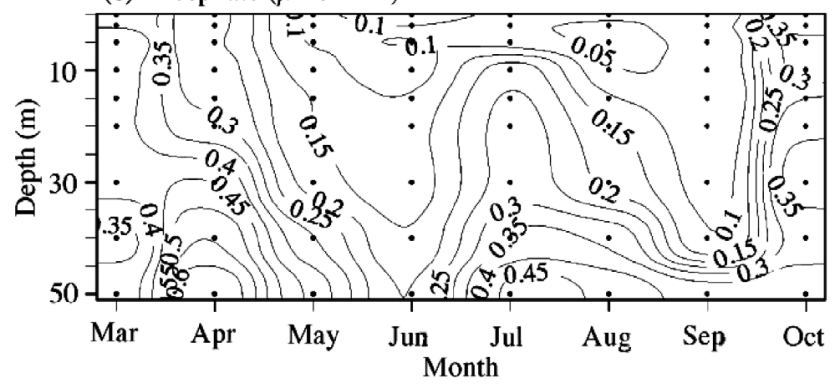

Fig. 4. Seasonal changes in the vertical distributions of (a) water temperature, (b) salinity, (c) nitrate + nitrite concentrations, (d) ammonium concentrations, and (e) phosphate concentrations 


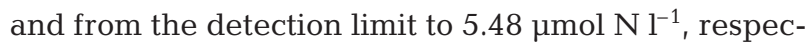
tively (Fig. 4c,d). The concentrations of nitrate + nitrite were relatively high in March $\left(>1 \mu\right.$ mol $\left.\mathrm{N} \mathrm{l}^{-1}\right)$,

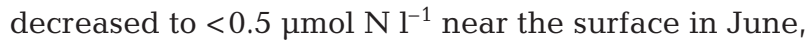
increased in the deeper layer (2.5 to $4 \mu \mathrm{mol} \mathrm{N} \mathrm{^{-1 }}$ ) due to the occurrence of bottom intrusion, and decreased again below the detection limit in August. Ammonium concentrations were low in April and May (Fig. 4d). The vertical distributions of the ammonium concentrations were similar to those of the nitrate + nitrite concentrations from June onwards. Seasonal changes in the vertical distribution of phosphate concentrations were similar to those of nitrate + nitrite concentrations (Fig. 4c,e). Relatively high phosphate concentrations ( 0.4 to $\left.0.3 \mu \mathrm{mol} \mathrm{P} \mathrm{l}^{-1}\right)$ were detected in March and October and in the deeper layer in July. Lower concentrations of both inorganic nitrogen and phosphorus were found when Kyucho occurred. When bottom intrusion occurred, these nutrient concentrations increased below a depth of $15 \mathrm{~m}$.

(a) Prochlorococcus ( $\mathrm{x} 10^{3}$ cells $\mathrm{ml}^{-1}$ )

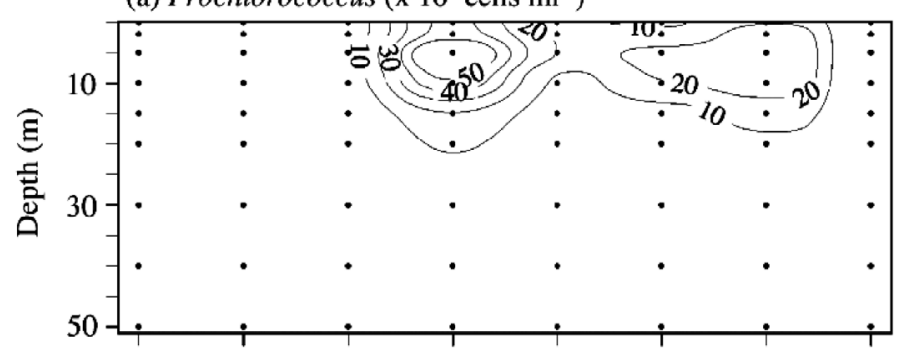

(b) Synechococcus $\left(\mathrm{x} 10^{3}\right.$ cells $\left.\mathrm{ml}^{-1}\right)$

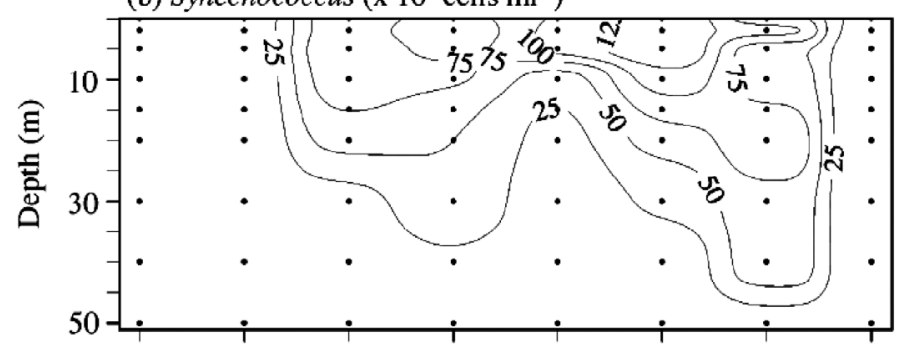

(c) Eukaryotic picophytoplankton $\left(\mathrm{x} 10^{3}\right.$ cells $\left.\mathrm{ml}^{-1}\right)$

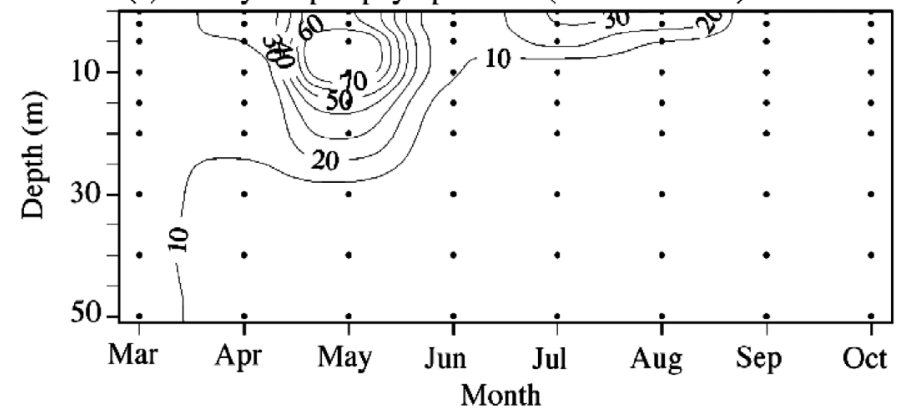

Fig. 5. Seasonal changes in the vertical distributions of (a) Prochlorococcus, (b) Synechococcus, and (c) eukaryotic picophytoplankton

\section{Seasonal changes in the abundance of picophyto- plankton in relation to Kyucho and bottom intrusion}

The abundance of picophytoplankton was high during the thermal stratification period (Fig. 5), though the vertical distributions of picophytoplankton were different among the 3 groups. The cell densities of Prochlorococcus were low $\left(<10^{3} \mathrm{cell} \mathrm{ml}^{-1}\right)$ before June, and high cell densities were detected at 0 to $15 \mathrm{~m}$ depths in June, with the highest value of $76.2 \times 10^{3} \mathrm{cells}^{-1}$ occurring at a $5 \mathrm{~m}$ depth (Fig. 5a). In August and September, relatively high cell densities were found at 5 to $15 \mathrm{~m}$ depths $\left(>22 \times 10^{3} \mathrm{cells} \mathrm{ml}^{-1}\right)$. Overall, the high densities corresponded to the occurrence of Kyucho.

Synechococcus was abundant from May to September, except for July (Fig. 5b). In June, August, and September, Synechococcus was distributed between depths of 0 to $30 \mathrm{~m}\left(41.5\right.$ to $154.9 \times 10^{3}$ cells ml $\left.^{-1}\right)$, though the vertical distribution of Prochlorococcus was limited to the upper $15 \mathrm{~m}$. The highest cell density $\left(154.9 \times 10^{5}\right.$ cells ml$\left.^{-1}\right)$ of Synechococcus was detected in August at a depth of $5 \mathrm{~m}$.

The maximum abundance of eukaryotic picophytoplankton $\left(93.9 \times 10^{3}\right.$ cells $\left.\mathrm{ml}^{-1}\right)$ was found in May (Fig. 5c). In June, August, and September, when Kyucho occurred, the cell densities of eukaryotic picophytoplankton were low. Relatively high densities ( 23.5 to $32.5 \times 10^{3}$ cells ml ${ }^{-1}$ ) were found at 0 and $5 \mathrm{~m}$ depths in July.

\section{Effects of nutrient addition on the growth rate of picophytoplankton}

The growth rates of Prochlorococcus were below $0 \mathrm{~d}^{-1}$ except for October (Table 1). We could not determine the growth rate from March to May because of the low cell densities $\left(<10^{3}\right.$ cells ml $^{-1}$, Fig. 5a). In October, positive growth rates ranging between 0.02 and $0.23 \mathrm{~d}^{-1}$ were found except in the urea and phosphate treatments. The growth rate in the urea treatment in October was relatively high $\left(0.23 \pm 0.13 \mathrm{~d}^{-1}\right)$, though no significant difference in the growth rate between the urea and control treatments could be detected.

The growth rates of Synechococcus in the control treatments varied from $0.04 \mathrm{~d}^{-1}$ in April to $1.05 \mathrm{~d}^{-1}$ in June (Table 1) and were higher than those of the eukaryotic picophytoplankton and Prochlorococcus. In most cases, the growth rates in the nutrient treatments were not significantly different from those in the control. The positive effects of ammonium, phosphate, urea, and phosphate addition were only detected in April.

The growth rate of eukaryotic picophytoplankton ranged from -0.10 to $0.59 \mathrm{~d}^{-1}$ in the control treatments (Table 1). In April and July, the cell density of eukary- 


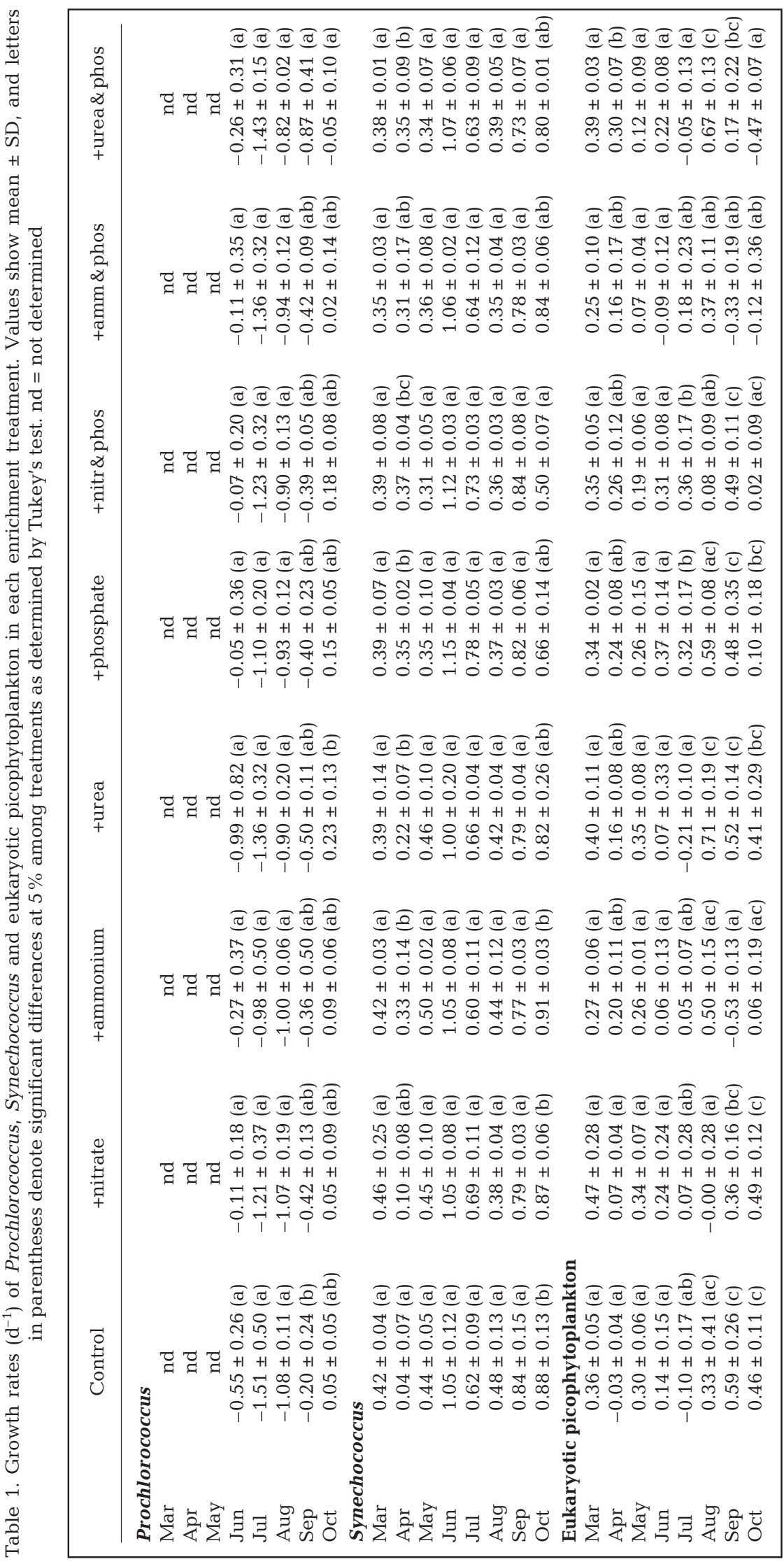

otic picophytoplankton in the control treatments decreased during incubation. In July, the addition of phosphate and nitrate and phosphate significantly stimulated the growth rate.

\section{DISCUSSION}

\section{Effects of Kyucho on the abundance of picophytoplankton}

In many coastal waters, Prochlorococcus is not generally detected (Partensky et al. 1999). In the present study, Prochlorococcus, which is considered oceanic (Partensky et al. 1999), was detected in the upper layer of Uchiumi Bay from June to October, when Kyucho occurred (Figs. 3a \& 5a). Some researchers also detected Prochlorococcus in coastal seas other than the Uwa Sea, such as the plume of the Rhone River in the Mediterranean Sea (Veldhuis \& Kraay 1990) and Suruga Bay, Japan (Shimada et al. 1995). It is controversial whether Prochlorococcus grows actively in coastal seas or is simply advected from the open ocean (Partensky et al. 1999). The present study provides an important insight into the controversy.

There are 2 possible reasons for our finding. One is the growth of Prochlorococcus in the bay, and the other, advection from the Pacific Ocean. In our incubation experiments, Prochlorococcus could not grow in control treatments (Table 1). Thus, the former possibility cannot fully explain the presence of Prochlorococcus in the bay. In contrast, the seawater of the Kuroshio, where Kyucho originates, contains an abundance of Prochlorococcus (Jiao et al. 2002). Moreover, the water temperature in the bay during winter usually decreases to $15^{\circ} \mathrm{C}$ (data not shown), which is the lower limit for the distribution of Prochlorococcus (Partensky et al. 1999). Moore et al. (1995) showed that a Prochlorococcus strain (SS120) could not grow at $12.5^{\circ} \mathrm{C}$. Thus, it is possible that Pro- 
chlorococcus in the bay cannot maintain its abundance in winter and serve as seed population for the next summer. Hence, the Prochlorococcus detected in the present study probably had been advected by Kyucho from the surface water of the Pacific Ocean.

The occurrence of Kyucho was also reported in Suruga Bay (Inaba et al. 2003), where Prochlorococcus was detected (Shimada et al. 1995). In addition to Uchiumi Bay and Suruga Bay, Kyucho also occurred in Sagami Bay (Matsuyama et al. 1999) and Sukumo Bay (Akiyama \& Saitoh 1993). These bays face the Kuroshio in the Pacific Ocean. Thus, there is a possibility that the transportation of Prochlorococcus by Kyucho occurred in the bays. Prochlorococcus may be detected in the bays after the occurrence of Kyucho.

In contrast, changes in the cell densities of Synechococcus after the occurrence of Kyucho (Figs. 3a \& 5b) were different from those of Prochlorococcus (Fig. 5a). A high abundance of Synechococcus was found in May, and the cell densities increased after the occurrence of Kyucho. Moreover, in June and September, a high abundance was found in the deeper layers, where the effects of Kyucho were negligible. In general, Synechococcus is ubiquitous from coastal waters to the open ocean (Olson et al. 1988, Campbell et al. 1998, Brown et al. 1999). In incubation experiments, high growth rates of Synechococcus in control treatments were observed during the investigation period. Thus, Synechococcus is transported by Kyucho and grows actively in Uchiumi Bay.

Eukaryotic picophytoplankton showed a different response to the occurrence of Kyucho (Figs. 3a \& 5c). The largest abundance during the investigation period was found in May. From June to October, when Kyucho occurred frequently, the abundance decreased. It is possible that the cell density of eukaryotic picophytoplankton in the Kuroshio is lower than that in the bay. In August 2001, we determined that eukaryotic picophytoplankton was abundant along a transect from the bay to offshore and found that the abundance of eukaryotic picophytoplankton in offshore areas was low relative to those in the bay ( $\mathrm{T}$. Hirose et al. pers. comm.). This result supports the possibility. It is likely that the low cell densities of eukaryotic picophytoplankton in the bay during the Kyucho were due to the flushing out of the picophytoplankton by the Kyucho from the bay.

\section{Effects of bottom intrusion on the abundance and growth of picophytoplankton}

The cell densities of Prochlorococcus decreased during the occurrence of bottom intrusion (Figs. 3a \& $5 \mathrm{a})$, though bottom intrusion supplies nutrients to the phytoplankton in the Uwa Sea (Koizumi \& Kohno 1994, Takeoka et al. 2000). In our incubation experiments, the growth of Prochlorococcus was not enhanced either with or without the addition of nitrogen and phosphorus nutrients (Table 1). Ammonium and urea, which are available forms of nitrogen for Prochlorococcus (Moore et al. 2002), also failed to stimulate Prochlorococcus growth (Table 1). Hence, it is likely that the growth of Prochlorococcus is limited by some environmental variables other than the supply of available nitrogen and phosphorus.

There are 2 possible reasons for the suppression of growth in Prochlorococcus, namely, the trace metal requirement and the metal toxicity. Saito et al. (2002) reported that Prochlorococcus has a cobalt requirement. In their experiments, zinc could not serve as a substitute for cobalt, though this is not the case for other phytoplankton species (Saito et al. 2002). With regard to the metal toxicity, Mann et al. (2002) demonstrated that the growth rate of Prochlorococcus was more susceptible than that of Synechococcus to a low level of the free cupric ion (free $\mathrm{Cu}^{2+}$ ). Contamination by toxic metals may be due to toxic elements from seawater or to those from incubation bottles that may have been inappropriately washed before experiments. However, the positive growth of Prochlorococcus in the control treatment was detected in October (Table 1), suggesting that our estimation seemed to be equivalent to the gross growth rate. Since there are many pearl oyster culture farms (Tomaru et al. 2002, Hashimoto \& Nakano 2003), Uchiumi Bay is heavily impacted by human activities. Thus, it is likely that the presence of toxic metal in seawater suppresses Prochlorococcus growth; however, we do not have any information on the metal concentrations in the bay. For more accurate estimation by bottle incubation, very stringent trace metal techniques are needed.

The positive growth found in October means that Prochlorococcus can grow in certain cases. Prochlorococcus in Uchiumi Bay may proliferate in cases where oceanic water entering the bay retains its qualities as a result of less mixing with the coastal water. Further studies will be needed to clarify the relationship between trace metal concentrations and the growth of Prochlorococcus.

Synechococcus decreased in abundance after bottom intrusion (Figs. 2a \& 5b). In the incubation experiments, the growth of Synechococcus was relatively high compared to that of other picophytoplankton groups and was not limited by the nutrient concentrations in most cases (Table 1). Nitrate and phosphate, both of which are major nutrients supplied by bottom intrusion (Koizumi \& Kohno 1994), did not stimulate the growth of Synechococcus (Table 1). It is well known that picophytoplankton has a high affinity for 
low levels of dissolved nutrients because of its high surface to volume ratio (Raven 1998). However, the growth rate of Synechococcus did not seem high enough to compensate for the loss of cells flushed from the bay.

In the present study, we could not find any difference in the growth rates of Synechococcus among various nitrogen forms (Table 1). It is known that different strains of Synechococcus respond differently to various nitrogen forms (Waterbury et al. 1986, Collier et al. 1999) and that Synechococcus consists of a diverse group of strains (Ferris \& Palenik 1998, Urbach et al. 1998, Honda et al. 1999). The pigmentation of Synechococcus in coastal waters differs from that of oceanic waters (Olson et al. 1990, Lantoine \& Neveux 1997, Wood et al. 1998), suggesting oceanic and coastal Synechococcus are genetically different. Thus, oceanic Synechococcus, which uses different nitrogen form(s), may be advected from Kuroshio to Uchiumi Bay by Kyucho. Further studies are needed to generalize the nitrogen utilization of Synechococcus in Uchiumi Bay.

Among the 3 groups of picophytoplankton, the growth response of eukaryotic picophytoplankton to bottom intrusion differed from those of Synechococcus and Prochlorococcus. The cell densities of eukaryotic picophytoplankton increased after bottom intrusion at depths of 0 to $5 \mathrm{~m}$ (Fig. 5b). In July, the growth rate of eukaryotic picophytoplankton was significantly stimulated in the phosphate and nitrate and phosphate treatments (Table 1). Nutrients supplied by bottom intrusion may stimulate the growth rate of eukaryotic picophytoplankton. A similar result was obtained in the Arabian Sea (Campbell et al. 1998). The abundance of eukaryotic picophytoplankton increased during the southwest monsoon, and thereafter, the contribution of eukaryotic picophytoplankton in depthintegrated carbon biomass reached $56.9 \%$ of total microbial biomass (Campbell et al. 1998). Thus, the response of eukaryotic picophytoplankton to the nutrient supply was similar to that of larger phytoplankton, such as diatoms. However, the growth of eukaryotic picophytoplankton was not significantly enhanced by nutrient additions in July (Table 1), though their cell densities increased after the occurrence of bottom intrusion. Our incubation was conducted at a $10 \mathrm{~m}$ depth, where the light intensity would be significantly reduced relative to that at the surface. Indeed, we did not detect high cell densities of eukaryotic picophytoplankton below a depth of $10 \mathrm{~m}$ in July (Fig. 5c), though the densities became high above $10 \mathrm{~m}$. Hence, it is likely that the light environment was not favorable to the growth of eukaryotic picophytoplankton.

In April, when the phosphate concentration was relatively high $\left(0.28 \mu \mathrm{mol} \mathrm{Pl^{-1 }}\right.$, Fig. $\left.4 \mathrm{e}\right)$, positive effects of phosphate addition on the growth rates of Synechococcus and eukaryotic picophytoplankton were detected (Table 1). By contrast, the growth rates of the 2 picoplankton were not stimulated by the addition of phosphate in June and August, when the phosphate concentration was low $\left(0.03 \mu \mathrm{mol} \mathrm{P} \mathrm{l}^{-1}\right)$. One possible reason for this was the difference in species, though no information on the species was available in the present study. Further analyses of the species composition of these picophytoplankton are needed.

In conclusion, the present study clearly demonstrates that the responses of the growth rate and abundance of picophytoplankton to the occurrence of Kyucho and bottom intrusion are different among the 3 groups. Drastic changes in the abundance of picophytoplankton and its composition due to these events may strongly affect the food linkage and flow of matter in the bay.

Acknowledgements. We are grateful to T. Hirose, K. Hyodo and other staff of Uchiumi Institute of Oceanic and Fishery Science, and the students of Ehime University, T. Hashimoto, D. Ichinotsuka, H.Ueno and R. Asaumi for their help in field monitoring. Thanks are also due to Dr. A. Yamashita for his help in analyzing nutrient concentration. The present study was partly supported by the Grant-in-Aid for Scientific Research No. 12308027, JSPS, and the Research Fund of coastal environment in Uchiumi Bay, Uchiumi Village, Ehime Prefecture.

\section{LITERATURE CITED}

Agawin NSR, Duarte CM, Agustí S (2000) Response of Mediterranean Synechococcus growth and loss rates to experimental nutrient inputs. Mar Ecol Prog Ser 206: 97-106

Akiyama H, Saitoh S (1993) The Kyucho in Sukumo Bay induced by Kuroshio warm filament intrusion. J Oceanogr 49:667-682

Brown SL, Landry MR, Barber RT, Campbell L, Garrison DL, Gowing MM (1999) Picophytoplankton dynamics and production in the Arabian Sea during the 1995 Southwest Monsoon. Deep-Sea Res II 46:1745-1768

Campbell L, Landry MR, Constantinou J, Nolla HA, Brown SL, Liu H, Caron DA (1998) Response of microbial community structure to environmental forcing in the Arabian Sea. Deep-Sea Res II 45:2301-2325

Collier JL, Brahamsha B, Palenik B (1999) The marine cyanobacterium Synechococcus sp. WH7805 requires urease (ureaamidohydrolase, EC 3.5.1.5) to utilize urea as a nitrogen source: molecular-genetic and biochemical analysis of the enzyme. Microbiol 145:447-459

Del Amo Y, Le Pape O, Tréguer P, Quéguiner B, Ménesguen A, Aminot A (1997) Impacts of high-nitrate freshwater inputs on macrotidal ecosystems. I. Seasonal evolution of nutrient limitation for the diatom-dominated phytoplankton of the Bay of Brest (France). Mar Ecol Prog Ser 161: 213-224

Duarte CM, Agusti S, Gasol JM, Vaqué D, VazquezDominguez E (2000) Effect of nutrient supply on the biomass structure of planktonic communities: an experimental test on a Mediterranean coastal community. Mar Ecol Prog Ser 206:87-95 
Fahnenstiel GL, Carrick HJ, Iturriaga R (1991) Physiological characteristics and food-web dynamics of Synechococcus in Lakes Huron and Michigan. Limnol Oceanogr 36: 219-234

Ferris M, Palenik B (1998) Niche adaptation in ocean cyanobacteria. Nature 396:226-228

Glover HE, Prezelin BB, Campbell L, Wyman M, Garside C (1988) A nitrate-dependent Synechococcus bloom in surface Sargasso Sea water. Nature 331:161-163

Hashimoto T, Nakano S (2003) Nutrient limitation on abundance and growth of phytoplankton in a Japanese pearl cultivation farm. Mar Ecol Prog Ser 258:43-50

Honda D, Yokota A, Sugiyama J (1999) Detection of seven evolutionary lineages in cyanobacteria based on the $16 \mathrm{~S}$ rRNA gene sequence analysis with new sequences of five marine Synechococcus strains. J Mol Evol 48:723-739

Inaba H, Yasuda K, Kawabata K, Katsumata T (2003) Kyucho in Suruga Bay in early March 1992. Oceanogr Jpn 12:59-67

Jiao N, Yang Y, Koshikawa H, Watanabe M (2002) Influence of hydrographic conditions on picoplankton distribution in the East China Sea. Aquat Microb Ecol 30:37-48

Kaneda A, Takeoka H, Koizumi Y (2002a) Periodic occurrence of diurnal signal of ADCP backscatter strength in Uchiumi Bay, Japan. Estuar Coast Shelf Sci 55:323-330

Kaneda A, Takeoka H, Nagaura E, Koizumi Y (2002b) Periodic intrusion of cold water from the Pacific Ocean into the bottom layer of the Bungo Channel, Japan. J Oceanogr 58:547-556

Koizumi Y (1991) A process of water exchange in Shitaba Bay during the phenomenon of Kyucho. Bull Coast Oceanogr 29:82-90

Koizumi Y, Kohno Y (1994) An influence of the Kyucho on a mechanism of diatom growth in Shitaba Bay in summer. Engankaiyou Kenkyu Note 32:81-89

Koizumi Y, Nishikawa S, Yakushiji F, Uchida T (1997) Germination of resting stage cells and growth of vegetative cells in diatoms caused by Kyucho events. Suisankaiyou Kenkyuu 61:275-287

Lantoine F, Nexeux J (1997) Spatial and seasonal variations in abundance and spectral characteristics of phytoplankton in the tropical northeastern Atlantic Ocean. Deep-Sea Res 44:223-246

Lindell D, Padan E, Post AF (1998) Regulation of ntcA expression and nitrate uptake in the marine Synechococcus sp. strain WH7803. J Bacteriol 180:1878-1886

Mann EL, Ahlgren N, Moffett JW, Chisholm SW (2002) Copper toxicity and cyanobacteria ecology in the Sargasso Sea. Limnol Oceanogr 47:976-988

Matsuyama M, Ishidoya H, Iwata S, Kitade Y, Nagamatsu H (1999) Kyucho induced by intrusion of Kuroshio water in Sagami Bay. Cont Shelf Res 19:1561-1575

Moore LR, Goericke R, Chisholm SW (1995) Comparative physiology of Synechococcus and Prochlorococcus: influence of light and temperature on growth, pigments, fluorescence and absorptive properties. Mar Ecol Prog Ser 116:259-275

Moore LR, Post AF, Rocap G, Chisholm SW (2002) Utilization of different nitrogen sources by the marine cyanobacteria Prochlorococcus and Synechococcus. Limnol Oceanogr 47:989-996

Mountin T, Thingstad TF, Wambeke FV, Marie D, Slawyk G, Raimbault P, Claustre H (2002) Does competition for nanomolar phosphate supply explain the predominance of the cyanboacterium Synechococcus? Limnol Oceanogr 47: 1562-1567

Editorial responsibility: Victor de Jonge (Contributing Editor), Haren, The Netherlands
Olson RJ, Chisholm SW, Zettler ER, Armbrust EV (1988) Analysis of Synechococcus pigment types in the sea using single and dual beam flow cytometry. Deep-Sea Res 35: 425-440

Olson RJ, Chisholm SW, Zettler ER, Armbrust EV (1990) Pigments, size, and distribution of Synechococcus in the North Atlantic and Pacific Oceans. Limnol Oceanogr 35: 45-58

Olson RJ, Zettler ER, DuRand MD (1993) Phytoplankton analysis using flow cytometry. In: Kemp PF, Sherr BF, Sherr EB, Cole JJ (eds) Handbook of methods in aquatic microbial ecology. Lewis Pubishers, Boca Raton, FL, p 175-186

Partensky F, Hess WR, Vaulot, D (1999) Prochlorococcus, a marine photosynthetic prokaryote of global significance. Microbiol Mol Biol Rev 63:106-127

Raven JA (1998) The twelfth Tansley lecture. Small is beautiful: the picophytoplankton. Funct Ecol 12:503-513

Saito MA, Moffett JW, Chisholm SW, Waterbury JB (2002) Cobalt limitation and uptake in Prochlorococcus. Limnol Oceanogr 47:1629-1636

Shimada A, Nishijima M, Maruyama T (1995) Seasonal abundance of Prochlorococcus in Suruga Bay, Japan in 1992-1993. J Oceanogr 51:189-300

Stockner JG, Antia NJ (1986) Algal picoplankton from marine and freshwater ecosystems: a multidisciplinary perspective. Can J Fish Aquat Sci 43:2472-2503

Takeoka H, Koizumi Y, Kaneda A. (2000) Year-to-year variation of a Kyucho and a bottom intrusion in the Bungo Channel, Japan. In: Yanagi $\mathrm{T}$ (ed) Interactions between estuaries, coastal seas and shelf seas. Terra Scientific Publishing, Tokyo, p 197-215

Thingstad TF, Zweifel UL, Rassoulzadegan F (1998) P limitation of heterotrophic bacteria and phytoplankton in the northwest Mediterranean. Limnol Oceanogr 43:88-94

Tomaru Y, Udaka N, Kawabata Z, Nakano S (2002) Seasonal change of seston size distribution and phytoplankton composition in bivalve pearl oyster Pinctada fucata martensii culture farm. Hydrobiologia 481:181-185

Urbach E, Scanlan DJ, Distel DL, Waterbury JB, Chisholm SW (1998) Rapid diversification of marine picophytoplankton with dissimilar light-harvesting structure inferred from sequences of Prochlorococcus and Synechococcus (cyanobacteria). J Mol Evol 46:188-201

Vaulot D, LeBot N, Marie D, Fukai E (1996) Effect of phosphorus on the Synechococcus cell cycle in surface Mediterranean waters during summer. Appl Environ Microbiol 62:2527-2533

Veldhuis MJW, Kraay GW (1990) Vertical distribution and pigment composition of a picoplanktonic prochlorophyte in the subtropical North Atlantic: a combined study of HPLC-analysis of pigments and flowcytometry. Mar Ecol Prog Ser 68:121-127

Waterbury JB, Watson SW, Valois FW, Franks DG (1986) Biological and ecological characterization of the marine unicellular cyanobacterium Synechococcus. Can Bull Fish Aquat Sci 214:71-120

Weisse $\mathrm{T}$ (1993) Dynamics of autotrophic picoplankton in marine and freshwater ecosystems. In Jones JG (ed) Advances in Microbiology Ecology, Vol 13. Plenum Press, New York, p 327-370

Wood AM, Phinney DA, Chisholm CS (1998) Water column transparency and the distribution of spectrally distinct forms of phycoerythrin containing organisms. Mar Ecol Prog Ser 162:25-31

Submitted: March 13, 2004; Accepted: February 6, 2005

Proofs received from author(s): July 28, 2005 